Funda Kosova*, Hanife Nurseven Şimşek and Nurcan Çelik

\title{
Evaluation of the clinical self-efficacy of postgraduate midwifery students who took courses related to biochemistry: a cross-sectional study
}

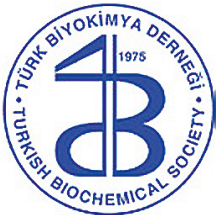

\section{[Biyokimya ile ilgili dersleri alan lisansüstü ebelik öğrencilerinin klinik öz-yeterliliklerinin değerlendirilmesi: kesitsel bir çalişma]}

https://doi.org/10.1515/tjb-2019-0238

Received May 26, 2019; accepted April 3, 2021; published online May 28, 2021

\section{Abstract}

Objectives: Postgraduate midwifery students learn the science and art of midwifery in clinical settings through the integration of evidence-based knowledge, practical skills, quality of care, and personal attitudes. These personal attitudes are confidence, intuition, problem solving, critical thinking, and self-efficacy. This study's goal was to evaluate the clinical self-efficacy of midwifery students

The study was presented as a poster at the "FEBS Workshop on Molecular Life Sciences: Training Tomorrow's Scientists" held on September 5-7, 2018, in Izmir.

*Corresponding author: Funda Kosova, Professor Doctor, Medical Biochemistry, Vocational School of Health Service, Manisa Celal Bayar University, Uncubozkoy Health Campus, Manisa, Turkey, Phone: +90 236 2318373/5858, E-mail: fundakosova@gmail.com. https://orcid.org/0000-0001-8070-5067

Hanife Nurseven Şimşek and Nurcan Çelik, Department of Midwifery, Faculty of Health Sciences, Manisa Celal Bayar University, Uncubozköy Health Campus, Manisa, Turkey,

E-mail: hanife.ege.2006@hotmail.com (H.N. Şimşek), nurcancelik35@yahoo.com.tr (N. Çelik). https://orcid.org/00000002-8307-6865 (H.N. Şimşek). https://orcid.org/0000-0002-43236430 (N. Çelik) who took courses related to biochemistry in the postgraduate education program.

Methods: A cross-sectional design was used in the study. In the study, data collection was performed using surveys from students in the postgraduate midwifery education program. The study data were collected by employing the "Introductory Information Form" and the "Self-efficacy for Clinical Evaluation Scale." Data evaluation was performed by number, percentage, mean, and correlation test.

Results: It was revealed that $67.7 \%$ of midwifery students who took the courses were postgraduate students in the thesis stage, $41 \%$ of them worked in secondary health services, and $51.6 \%$ of them had a clinical experience of 5 years and more. The total score of the self-efficacy perception subscale was $4.22 \pm 0.49(1-5)$, whereas the total score of the perceived confidence subscale was $4.57 \pm 0.45$ (1-5). There was a statistically significant correlation between the self-efficacy subscale and the importance subscale.

Conclusions: The results indicated that postgraduate midwifery students had high clinical self-efficacy scores. We think that the elective courses related to biochemistry in the postgraduate midwifery education program may have positively affected their clinical skills. We anticipate that it will be appropriate to conduct research with a larger sample size to examine the effect of postgraduate midwifery education on students' clinical self-efficacy.

Keywords: biochemistry; midwifery; postgraduate; selfefficacy. 


\section{Öz}

Amaç: Lisansüstü ebelik öğrencileri, kanıta dayalı bilgi, pratik beceriler, bakım kalitesi ve kişisel tutumların entegrasyonu ile klinik ortamdaki ebelik bilim ve sanatını öğrenirler. Bu kişisel tutumlar güven, sezgi, problem çözme, eleştirel düşünme ve öz-yeterliliktir. Çalışmanın amacı, lisansüstü eğitim programında biyokimya ile ilgili dersleri alan ebelik öğrencilerinin klinik öz-yeterliliklerini berlirlemektir.

Materyal ve Metod: Araştırma, kesitseldir. Araştırma verileri, üniversitenin lisansüstü ebelik eğitim programındaki öğrencilerden anketlerle toplanmıştır. Araştırmanın verileri "Tanıtıcı Bilgi Formu" ve "Klinik Değerlendirme Öz-yeterlilik Ölçeği” kullanılarak toplanmıştır. Veriler sayı, yüzde, ortalama ve korelasyon testi ile değerlendirilmiştir. Bulgular: Dersleri alan ebelik yüksek lisans öğrencilerinin \%67.7'sinin tezli yüksek lisans öğrencisi olduğu, \%41.9'unun ikinci basamak sağlık hizmetlerinde çalıştığı, \%51.6'sının beş yıl ve üzerinde klinik deneyimi olduğu saptanmıştır. Öğrencilerin tamamı, derslerin gerekli olduğunu ve mesleki olarak katkı sağladığını belirtmişlerdir. Ölçeğin öz-yeterlilik algısı alt boyutundan alınan toplam puan $4.22 \pm 0.49$ iken, algilanan güven alt boyutundan alınan toplam puan $4.57 \pm 0.45^{\prime}$ tir. Öz-yeterlik alt boyutu ile önem alt boyutu arasında istatistiksel olarak anlamlı bir ilişki vardır.

Sonuç: Sonuçlar lisansüstü ebelik öğrencilerinin klinik öz-yeterlilik puanlarının yüksek olduğunu göstermiştir. Lisansüstü ebelik eğitim programında biyokimya ile ilgili seçmeli dersler, öğrencilerin klinik becerilerini olumlu yönde etkilemiş olabileceğini düşünmekteyiz. Lisansüstü ebelik eğitiminin, öğrencilerin klinik özyeterlilikleri üzerindeki etkisini incelemek için daha büyük örneklem büyüklüğü ile yapmanın uygun olacağını öngörmekteyiz.

Anahtar Kelimeler: biyokimya; Ebelik; lisansüstü; özyeterlilik.

\section{Introduction}

Midwifery has advanced into a professionalized and specialized field in the world [1, 2]. Midwives who have successfully completed a midwifery bachelor education program are registered to postgraduate education programs as specialists in midwifery [2]. Postgraduate programs enable students to learn the basics of midwifery philosophy and acquire clinical and academic thinking. The clinical setting can make students' ability to integrate theory and practice more comprehensible. Midwifery students learn the science and art of midwifery in clinical settings through the integration of evidence-based knowledge, practical skills, quality of care, and personal attitudes. These personal attitudes are confidence, intuition, problem solving, critical thinking, and self-efficacy $[1,3-6]$. The self-efficacy theory of Bandura is described as the personal belief about the capability to cope with a specific situation [7]. Self-efficacy consists of two parts: outcome expectation and efficacy expectation. Outcome expectation is the belief that a particular behavior will generate the desired result. Efficacy expectation represents the personal belief that an individual can successfully implement these behaviors to achieve the desired outcome [8].

Biochemistry is an important area of knowledge in the basics of health courses [9]. Postgraduate courses related to biochemistry incorporate in-depth knowledge about the core topics in each specialty along with skills for the clinical laboratory. It is very important for midwifery students to associate laboratory findings with clinical presentation [10] because midwifery has an independent and articulated philosophical doctrine and hallmarks of care, including autonomy, therapeutic presence, competency, confidence, and critical thinking in performing midwifery care in clinical settings and urgent situations. Thus, there is a need for professionalized, competent, and confident midwives, and midwifery postgraduate students require a lot of support to acquire these. The importance of being a competent midwife with the confidence to practice, including the ability to take critical decisions in urgent situations, thus, professional autonomy is essential [5, 8].

Nevertheless, studies focusing on enhancing clinical competence among self-efficacy and related to biochemistry courses are lacking. This study aimed to assess the clinical self-efficacy of midwifery students who took courses related to biochemistry in the postgraduate education program.

\section{Methods}

\section{Study design}

A cross-sectional design was employed in the study. The aim of the study is descriptive, often in the form of a survey. Usually, a hypothesis as such is absent. However, the aim is to describe a population or a subgroup within the population concerning an outcome.

\section{Participants}

The research was conducted in a postgraduate midwifery education program in the Department of Midwifery, Institute of Health Sciences, Manisa Celal Bayar University. This Institute of Health Sciences 
has Master of Sciences (M.Sc.) and Doctor of Philosophy (Ph.D.) degrees in postgraduate midwifery education. The participants were postgraduate midwifery students registered for the Vitamins in Pregnancy, Woman and Hormone, and Pregnant Biochemistry courses, respectively, during the 2015-2018 academic year. The courses were elective for students registered for all postgraduate programs in the Department of Midwifery. All students completed these courses of $24 \mathrm{~h}$ in a 14 week period during 2015-2018. Topics were presented to students so that they could explain them by the PowerPoint method. These courses are taught weekly to postgraduate midwifery students using the face-to-face method of delivery.

\section{Data collection}

Data were collected using two questionnaires.

Introductory information form: It was prepared by the researcher and included 11 questions in two main categories (I) background information (four items) and (II) questions related to biochemistry courses (seven items).

Self-efficacy for Clinical Evaluation Scale: It was developed by Clark et al. [10] and adapted to Turkish by Zengin et al. [11, 12]. The SECS is a five-point Likert-type scale, consisting of 30 items, with scores ranging from " 1 to 5 ." The scale includes two subscales of perceived self-efficacy and perceived importance. The first subscale measures students' self-efficacy perceptions related to care skills for patients with chronic diseases in clinical settings, and the second subscale evaluates the importance attached to the mentioned skills by students. A low score indicates that a student is not confident in providing care to patients and also does not attach adequate importance to providing care. Clark et al. [10] revealed that Cronbach's alpha reliability value was 0.98 for the self-efficacy subscale and 0.95 for the perceived importance subscale. In this study, Cronbach's alpha value was found to be 0.94 for the self-efficacy subscale and 0.92 for the perceived importance subscale.

\section{Analysis}

All data were analyzed by utilizing the SPSS version with descriptive statistics such as mean, standard deviation, frequency, percentage, and correlation. Statistical significance was set at a p-value below 0.05 .

\section{Ethical considerations}

Ethics approval for the study was obtained from the University Human Research and Ethics Committee. All students were informed that participation was voluntary and provided written consent to participate.

\section{Results}

There were 59 students enrolled in the postgraduate midwifery education program, and 31 students completed the questionnaires. The background information of the students is shown in Table 1. The mean age of the students at post-graduation was $29.83 \pm 6.78$ years.

As shown in Table 2, postgraduate midwifery students had high perceived self-efficacy and perceived importance scores. This study showed that postgraduate midwifery students had quite high clinical self-efficacy.

Table 3 shows the correlation between age, work experience, perceived self-efficacy, and perceived importance. There is a statically significant correlation between the perceived self-efficacy subscale scores and perceived importance subscale scores ( $\mathrm{p}<0.05)$, which is a low positive correlation. This study showed that no statistically significant difference was present between self-efficacy and age, nor with work experience ( $p>0.05)$.

\section{Discussion}

Postgraduate midwifery education provides the knowledge and practice of midwifery and advances the profession [13]. This study's goal was to assess the clinical self-efficacy of midwifery students who took courses related to

Table 1: Descriptive characteristics of postgraduate midwifery students.

\begin{tabular}{|c|c|c|}
\hline Characteristics & $\mathbf{n}$ & Percentage, \% \\
\hline \multicolumn{3}{|l|}{ Age in years } \\
\hline Under 30 years & 19 & 61.3 \\
\hline 30 years and over & 12 & 38.7 \\
\hline \multicolumn{3}{|l|}{ Postgraduate education } \\
\hline Thesis master's program & 21 & 67.7 \\
\hline Non-thesis master's program & 10 & 32.3 \\
\hline \multicolumn{3}{|l|}{ Perception of income } \\
\hline Low income & 3 & 9.7 \\
\hline Medium income & 21 & 67.7 \\
\hline High income & 7 & 22.6 \\
\hline \multicolumn{3}{|l|}{ Present workplace } \\
\hline Primary health care & 12 & 38.7 \\
\hline Secondary health care & 13 & 41.9 \\
\hline Other & 6 & 19.4 \\
\hline \multicolumn{3}{|l|}{ Years of work experience } \\
\hline Under 5 years & 15 & 48.4 \\
\hline 5 years and over & 16 & 51.6 \\
\hline \multicolumn{3}{|l|}{ Courses are necessary } \\
\hline Yes & 31 & 100.0 \\
\hline No & 0 & \\
\hline \multicolumn{3}{|l|}{ Content of the courses is sufficient } \\
\hline Yes & 30 & 96.8 \\
\hline No & 1 & 3.2 \\
\hline \multicolumn{3}{|c|}{ Courses have increased professional competence } \\
\hline Yes & 31 & 100.0 \\
\hline No & 0 & \\
\hline Total & 31 & 100.0 \\
\hline
\end{tabular}


Table 2: Distribution of the self-efficacy for clinical evaluation scale scores of postgraduate midwifery students.

\begin{tabular}{lrr}
\hline Characteristics & Min-max & Mean \pm SD \\
\hline Scale & & \\
Perceived self-efficacy & $1-5$ & $4.22 \pm 0.49$ \\
Perceived importance & $1-5$ & $4.57 \pm 0.45$ \\
\hline
\end{tabular}

Table 3: Correlation between the self-efficacy for clinical evaluation scale and other variables.

\begin{tabular}{lrrc}
\hline & Age & $\begin{array}{r}\text { Work experi- } \\
\text { ence, years }\end{array}$ & $\begin{array}{c}\text { Self- Importance } \\
\text { efficacy }\end{array}$ \\
\hline $\begin{array}{l}\text { Age } \\
\begin{array}{l}\text { Work experi- } \\
\text { ence, years }\end{array}\end{array}$ & 0.000 & 1 & \\
$\begin{array}{l}\text { Perceived self- } \\
\text { efficacy }\end{array}$ & 0.060 & 0.260 & 1 \\
$\begin{array}{l}\text { Perceived } \\
\text { importance }\end{array}$ & -0.197 & 0.164 & 0.029 \\
\hline
\end{tabular}

biochemistry in the postgraduate education program. Midwives complete their bachelor education and then may receive academic degrees in other disciplines such as medicine and nursing [13].

Gijbels et al. showed that postgraduate midwifery and nursing education had an impact on changing students' attitudes and perceptions and acquiring academic knowledge and skills [13]. Nicolson et al. found that postgraduate course experience increased confidence and assertiveness in practice [14]. Hardwick and Jordan reported that postgraduate midwifery and nursing students' practice had changed as a result of the skills and knowledge acquired in their courses. Most of the students used their graduate skills in practice [15]. Spencer reported that postgraduate education had a positive effect on practice [16]. Goswami et al. conducted a study showing that postgraduate medical biochemistry students had an improvement in biochemical concepts and solving of a similar clinical problem [10]. In the present research, we determined a statistically significant difference between the self-efficacy subscale and the importance subscale. Professional confidence is among the most important factors because midwives are typically autonomous practitioners.

Bäck et al. found that it was not necessary for midwives to have worked for 20 years to gain competence [8]. In another study performed by Back et al., it was shown that external and internal factors such as clinical environment, self-efficacy, and confidence contributed to work experience [5]. Yucel et al. showed that postgraduate education had a positive impact on the working life of most midwives [1]. The present study showed that the work experience of postgraduate midwifery students had a statistically significant difference compared to age. However, professional experience is a process.

Larsson et al. reported that professional identity consisted of thinking, reflection, and art of midwifery, and it took many years to acquire these [17]. Mollart et al. found that midwives who had spent 21 years or more in the profession experienced the most exhilaration compared to other professional groups [18]. We showed that no statistically significant difference was present between self-efficacy and age, nor with work experience. However, work experience was statistically significant when age did not display a significant difference compared to perceived importance. Since midwives have more years of work experience and have a more realistic perspective, they may not be as prone to burnout.

\section{Conclusions}

We have concluded that the courses related to biochemistry may positively affect the clinical skills of graduate midwifery students. More research is needed to examine the impact of the postgraduate training program on students' clinical self-efficacy. However, we recommend conducting research with a larger sample size to examine the effect of postgraduate midwifery education on clinical practice. We think that our study will benefit researchers working on this subject.

\section{Study limitations}

This study has some limitations. This study was carried out at a single state university. Given that the sample size was only 31 respondents, the results cannot be generalized to other groups. Because of variation in postgraduate midwifery programs worldwide, it is very difficult to comment on this subject.

Acknowledgments: We would like to thank all the postgraduate midwifery students who participated in our study and spent their time.

Competing interest: The authors have no personal, professional, and financial conflict of interest to disclose. 


\section{References}

1. Yücel U, Ekşioğlu A, Demirelöz M, Baykal Akmeşe Z, Çakır Koçak Y, Soğukpınar N. Türkiye'de ebelik lisansüstü eğitim profilinin incelenmesi. Int J Hum Sci 2013;10:1342-54.

2. Maree C, Yazbek M, Leech R. Process of development of a contemporary curriculum in advanced midwifery. Health SA Gesondheid 2018: 2071-9736.

3. Yilmaz T, Karanisoğlu H. Türkiye'de Ebelik Eğitiminin Güncel Durumu. Sağlık Bilimleri ve Meslekleri Dergisi 2016;3:73-7.

4. Ebert L, Tierney 0 , Jones $D$. Learning to be a midwife in the clinical environment; tasks, clinical practicum hours or midwifery relationships. Nurse Educ Pract 2016;16:294-7.

5. Back L, Hildingsson I, Sjoqvist C, Karlstrom A. Developing competence and confidence in midwifery-focus groups with Swedish midwives. Women Birth 2017;30:e32-8.

6. Goyet S, Sauvegrain P, Schantz C, Morin C. State of midwifery research in. Midwifery 2018;64:101-9.

7. Bäck L, Sharma B, Karlström A, Tunon K, Hildingsson I. Professional confidence among Swedish final year midwifery students-A crosssectional study. Sex Reprod Healthc 2017;14:69-78.

8. Drummond J, Rickwood D. Childbirth confidence: validating the childbirth self-efficacy inventory (CBSEI) in an Australian sample. J Adv Nurs 1997;26:613-22.

9. Goswami B, Jain A, Koner BC. Evaluation of brainstorming session as a teaching-learning tool among postgraduate medical biochemistry students. Int J Appl Basic Med Res 2017;7(1 Suppl): 15-8.
10. Clark MC, Owen SV, Tholcken MA. Measuring student perceptions of clinical competence. J Nurs Educ 2004;43:548-54.

11. Zengin N, Pınar R, Akinci AC, Yildiz H. Psychometric properties of the self-efficacy for clinical evaluation scale in Turkish nursing students. J Clin Nurs 2014;23:976-84.

12. Hermansson E, Mårtensson LB. The evolution of midwifery education at the master's level: a study of Swedish midwifery education programmes after the implementation of the Bologna process. Nurse Educ Today 2013; 33:866-72.

13. Gijbels H, O'Connell R, Dalton-O'Connor C, O'Donovan M. A systematic review evaluating the impact of post-registration nursing and midwifery education on practice. Nurse Educ Pract 2010;10:64-9.

14. Nicolson P, Jennifer Burr J, Powell J. Becoming an advanced practitioner in neonatal nursing: a psycho-social study of the relationship between educational preparation and role development. J Clin Nurs 2005;14:727-38.

15. Hardwick S, Jordan S. The impact of part-time post-registration degrees on practice. J Adv Nurs 2002;38:524-35.

16. Spencer RL. Nurses', midwives' and health visitors' perceptions of the impact of higher education on professional practice. Nurse Educ Today 2006;26:45-53.

17. Larsson M, Aldegarmann U, Aarts C. Professional role and identity in a changing society: three paradoxes in Swedish midwives' experiences. Midwifery 2009;25:373-81.

18. Mollart L, Skinner VM, Newing C, Foureur M. Factors that may influence midwives work-related stress and burnout. Women Birth 2013;26:26-32. 